\title{
PENGEMBANGAN BAHAN AJAR MATEMATIKA \\ BERBASIS MACROMEDIA FLASH MATERI OPERASI BILANGAN REAL SMK TEKNOLOGI \& REKAYASA
}

\author{
Anggita Maharani \\ Prodi Pendidikan Matematika FKIP Universitas Swadaya Gunung Jati (UNSWAGATI) \\ Email: anggi3007@yahoo.co.id
}

\begin{abstract}
ABSTRAK
Untuk memaksimalkan penggunaan komputer sebagai sarana penunjang pembelajaran, perlu dikembangkan bahan ajar berbasis TIK. Sebagai upaya untuk mengitegrasikan TIK dalam proses pembelajaran, perlu adanya pengembanganbahan ajar yang berbasis teknologi seperti $C D$ atau video. Tujuan penelitian adalah memperolehbahan ajar matematikaberbasis micromdia flash yang valid. Model pengembangan yang digunakan adalah modifikasi model Thiagarajanatau yang disebut Four-D Model.Berdasarkan proses dan hasil penelitian pengembangan dapat diketahui bahwa proses produksi bahan ajar dilakukan dalam rangka mengembangkan bahan ajar matematika untuk siswa SMK materi Operasi Bilangan Real pokok bahasan Perbandingan, Skala dan Persen menggunakan software macromedia flash. Bahan ajar berbasis macromedia flash yang dikembangkan, desainnya memuat permasalahan dalam kehidupan sehari-hari khususnya dalam aplikasi Operasi Bilangan Real terhadap perhitungan teknik otomotif. Deskripsi hasil validasi pada tahap pengembangan, menunjukkan bahwa hasil validasi dari ahli media dalam kategori valid, validasi ahli isi/materi dalam kategori valid, dan hasil dari validasi ahli pembelajaran juga dalam kategori valid.
\end{abstract}

Kata Kunci: Bahan Ajar, Macromedia Flash, SMK 


\section{PENDAHULUAN}

Seiring dengan perkembangan
teknologi, saat ini mulai banyak dikembangkan berbagai media pembelajaran sebagai salah satu bentuk bahan ajar. Salah satu dari media pembelajaran yang mulai dikembangkan adalah media berbasis TIK (Teknologi, Informasi dan Komunikasi). Hasil penelitian Harliawan, dkk (2014) menunjukkan bahwa penggunaan media pembelajaran berbasis TIK dapat meningkatkan hasil belajar siswa. Melalui pembelajaran dengan menggunakan media berbasis TIK, peserta didik disiapkan untuk memaknai segala informasi dan menciptakannya menjadi pengetahuan untuk kemudian dapat menggunakan dan mengevaluasi yang diciptakan oleh orang lain (Halidi, dkk. 2015).

Berdasarkan indikator TIK Indonesia tahun 2015 (Kementrian Komunikasi dan Informasi Republik Indonesia, 2015) dapat diketahui hanya 29,8\% keluarga di Indonesia yang memiliki akses terhadap komputer. Dari data tersebut juga dapat diketahui bahwa ada perbedaan yang signifikan antara pengguna komputer di perkotaan dan pedesaan, dimana proporsi masyarakat pengguna komputer di perkotaan jauh lebih tinggi jika dibanding pedesaan. Jika dibandingkan dengan karyawan swasta dan PNS/TNI/Polri, prosentase pengguna komputer oleh pelajar/mahasiswa masih lebih rendah.Hal ini menunjukkan bahwa media pembelajaran berbasis TIK belum maksimal digunakan oleh pelajar/mahasiswa. Namun demikian, data hasil survey menunjukkan bahwa untuk 3 tahun terakhir akses rumah tangga terhadap komputer mengalami peningkatan yang signifikan.

Hasil survey menunjukkan bahwa hampir sebagian sekolah sudah memiliki fasilitas teknologi seperti LCD dan lab komputer. Minimnya penggunaan komputer, pada umumnya disebabkan oleh minimnya pengetahuan guru akan penggunaan media pembelajaran. Sebagian besar guru memahami penggunaan media pembelajaran hanya sebatas power point yang isinya adalah rangkuman materi pelajaran. Hasil survey ini sesuai dengan hasil penelitian Chang, dkk (2006) dimana penggunaan software bagi guru merupakan suatu hal yang penting namun proses integrasi di dalam kelas biasanya diabaikan.

Untuk memaksimalkan penggunaan komputer sebagai sarana penunjang pembelajaran, perlu dikembangkan bahan ajar berbasis TIK. Matematika sebagai bagian dari struktur kurikulum SMK, merupakan program kurikuler yang bertujuan mengembangkan kompetensi sikap, kompetensi pengetahuan, dan kompetensi keterampilan peserta didik sebagai dasar penguatan kemampuan dalam kehidupan bermasyarakat, berbangsa, dan bernegara (Permendikbud, 2014). Agar tujuan pembelajaran mencapai sasaran dengan tepat, selain pemilihan metode pembelajaran yang sesuai juga perlu adanya bahan ajar yang dikembangkan sesuai kebutuhan siswa SMK serta kemajuan teknologi. Untuk itu, melalui penelitian ini akan dikembangkan bahan ajar matematika berbasis Micromedia Flash untuk siswa kelas X SMK Teknologi \& Industri.

\section{KAJIAN TEORI}

\section{Media Pembelajaran Macromedia Flash}

Media merupakan sesuatu yang dimanfaatkan untuk proses komunikasi dengan siswa agar siswa belajar. Komunikasi dan siswa yang belajar (leaners) merupakan dua aspek pokok. Media/alat peraga pembelajaran merupakan alat-alat yang digunakan guru dalam pembelajaran untuk membantu memperjelas materi pelajaran dan mencegah terjadinya verbalisme pada diri siswa.

Seperti yang dipaparkan oleh Rahman, dkk (2008), bahwa Macromedia Flash adalah software yang dipakai luas oleh para profesional web karena kemampuannya dalam menggabungkan unsur teks, grafis, suara, animasi, dan interaksi pengguna program animasi internet. Macromedia Flash (Flash MX) merupakan sebuah program aplikasi standar authoring tool profesional yang digunakan untuk membuat animasi vektor 
dan bitmap yang sangat menakjubkan untuk keperluan pembuatan situs web yang interaktif dan dinamis. Selain itu, aplikasi ini juga dapat digunakan untuk membuat animasi logo, movie, game, pembuatan navigasi pada situs web, banner, tombol animasi, menu interaktif, interaktif form isian, e-card, screen saver dan pembuatan keseluruhan isi web atau pembuatan aplikasi-aplikasi web lain.

Lebih lanjut Rahman, dkk (2008) mengatakan animasi dan gambar yang dibuat dengan flash dapat terlihat bagus untuk ukuran windows dan resolusi layar berapapun. Hal ini terjadi karena flash dibuat dengan teknologi vector graphic sehingga ukurannya dapat diubah sesuai kebutuhan tanpa mengurangi atau mempengaruhi kualitas dari gambar tersebut. Waktu loading, animasi gambar yang muncul lebih cepat dibanding dengan program-program animasi lainnya. Selain itu flash mampu membuat animasi grafis yang rumit dengan sangat cepat, sehingga membuat animasi layar penuh bisa langsung disambung ke situs web.

\section{Bahan Ajar}

Bahan ajar merupakan kelengkapan yang diperlukan dan dipergunakan oleh guru ketika mengajar. Sesuai dengan isi pada juknis pengembangan bahan ajar SMA yang disampaikan direktorat Pembinaan SMA (2010) bahwa bahan ajar adalah segala bentuk bahan berupa perangkat materi yang disusun secara sistematis yang digunakan untuk membantu guru dalam melaksanakan kegiatan pembelajaran dan memungkinkan peserta didik untuk belajar.

\section{Jenis bahan ajar berupa:}

a. Bahan ajar cetak (printed), antara lain hand out, buku, modul, poster, brosur, lembar kerja siswa (LKS), wallchart, foto atau gambar, dan leaflet;

b. Bahan ajar dengar (audio) seperti kaset, radio, piringan hitam, dan compact disk audio;

c. Bahan ajar pandang dengar ( audio visual) seperti compact disk video, film;

d. Bahan ajar multimedia interaktif (interactive teaching material) seperti
CAI (Computer Assisted Instruction), compact disk (CD) multimedia pembelajaran interaktif, dan bahan ajar berbasis web (web based learning materials).

Prinsip pengembangan bahan ajar adalah:

a. relevansi atau keterkaitan materi sesuai dengan tuntutan Standar Kompetensi/Kompetensi Dasar;

b. konsistensi atau keaje gan, dimaksudkan jika kompetensi dasar yang harus dicapai peserta didik ada empat macam, maka bahan ajarnya pun harus empat macam;

c. adekuasi atau kecukupan adalah kecukupan materi dalam bahan ajar untuk mencapai kompetensi seperti yang diajarkan oleh guru.

Bahan ajar berbasis TIK merupakan bahan ajar yang menggunakan teknologi sebagai alat bantu dalam mengolah data, termasuk memproses, mendapatkan, menyusun, menyimpan, memanipulasi data dalam berbagai cara untuk menghasilkan informasi yang berkualitas.

\section{Bahan Ajar Matematika berbasis Macromedia Flash}

Pendidikan matematika memiliki potensi besar dalam menyiapkan sumber daya manusia untuk menghadapi era industrialisasi dan globalisasi. Potensi ini dapat terwujud jika pendidikan matematika mampu melahirkan peserta didik yang cakap dalam matematika dan berhasil menumbuhkan kemampuan berfikir logis, kritis, dan inovatif terhadap menanggapi perubahan dan perkembangan.

Teknologi secara substansi telah menjadi bagian yang terintegrasi dalam kehidupan manusia sejak ribuah tahun yang lalu. Seiring dengan perjalanan peradaban manusia yang terus berkembang, teknologi terus berubah dan berkembang semakin canggih dan kompleks.

Perkembangan ilmu pengetahuan dan teknologi memungkinkan semua pihak dapat memperoleh informasi dengan melimpah, cepat, dan mudah dari berbagai sumber dan tempt di dunia. Dengan demikian, siswa 
perlu dibekali kemampuan memperoleh, memilih, dan mengelola informasi untuk bertahan pada keadaan yang selalu berubah, tidak pasti, dan kompetitif. Kemampuan ini membutuhkan pemikiran kritis, sistematis, logis, kreatif dan kemauan bekerjasama yang efektif. Cara berfikir seperti inilah yang dikembangkan dalam matematika karena matematika memiliki struktur dan keterkaitan yang kuat dan jelas antar konsepnya sehingga memungkinkan siswa terampil dan berfikir rasionalDalam mempelajari kompetensi keahlian otomotif, banyak perhitunganperhitungan yang dipakai seperti diantaranya adalah perhitungan yang dilakukan untuk mengatahui kapasitas mesin, volume silinder, perbandingan kompresi, kecepatan piston, torsi, tenaga, korelasi antara mesin dan kecepatan motor pada tiap posisi gigi dan daya dorong roda belakang sepeda motor, dll. Dengan demikian, secara umum pembelajaran matematika dapat membentuk kecakapan kejuruan siswa jika diarahkan dengan benar.

Untuk mendukung keberhasilan analisis teknologi otomotif, penyajian matematika tentunya perlu dikoordinasikan dengan penyajian kompetensi otomotif. Hal ini diperlukan agar topik matematika yang disajikan dapat memberikan landasan aplikasi permasalahan analisis dalam teknologi otomotif.Kelebihan-kelebihan Macromedia Flash $M X$ dapat dimanfaatkan dalam dunia pendidikan khususnya dalam penyediaan bahan ajar. Bahan ajar dapat dirancang dengan cara menggabungkan animasi huruf dan gambar sehingga tampilannya menarik.

\section{METODE PENELITIAN}

Model yang digunakan untuk mengembangkan bahan ajar dalam penelitian ini adalah modifikasi model Thiagarajan (dalam Trianto 2007:65) yakni Four-D Model. Deskripsi pengembangan bahan ajar menggunakan model pengembangan Four-D, diuraikan sebagai berikut:

\section{Tahap Pendefinisian (define)}

Tahap ini meliputi:Analisis ujung depan, Analisis siswa, Analisis Tugas,
Analisis Konsep/materi, Perumusan Tujuan Pembelajaran.

\section{Tahap Perancangan (design)}

Hasil pada tahap perancangan ini disebut Draft bahan ajar. Materi pembelajaran mengacu pada hasil analisis materi, hasil analisis tugas dan indikator hasil belajar yang telah dirumuskan pada tahap pendefinisian. Kegiatan perancangan (design) meliputi:
a. Pembuatan story board
b. Pembuatan layout tampilan media interaktif
c. Penulisan materi
d. Penambahan efek suara, video, animasi, dan gambar

\section{Tahap Pengembangan (develop)}

Kegiatan pada tahap ini meliputi:

a. Validasi oleh para pakar diikuti dengan revisi

Tahap pengembangan dengan penilaian oleh ahli. Penilaian dilakukan terhadap bahan ajar matemtika berbasis macromedia flashyang dikembangkan pada tahap perancangan (Draft I), sehingga menghasilkan bahan ajar final. Ahli yang dimaksud adalah para validator yang berkompeten pada materi matematika SMK dan ahli media meliputi pengajar pendidikan matematika (dosen), teman sejawat, serta guru mata pelajaran matematika. Bahan ajar matematika berbasis macromedia flashyang telah diberi penilaian, kemudian dilakukan revisi berdasarkan masukan dan saran para ahli tersebut.

b. Uji coba Bahan Ajar

Uji coba bahan ajar di kelas bertujuan untuk mengetahui kejelasan, keterbacaan, dan kecocokan antara waktu yang direncanakan dalam rencana pembelajaran dengan pelaksanaannya. Hasil yang diperoleh dari uji coba ini selanjutnya digunakan untuk merevisi bahan ajar.

\section{Tahap Penyebaran (Desseminate)}

Pengembangan bahan ajar matematika berbasis macromedia flashmencapai tahap akhir jika telah memperoleh nilai positif dari tenaga ahli dan melalui tes pengembangan 
bahan ajar tersebut kemudian dikemas, disebarkan dan diterapkan untuk skala yang lebih luas.

Modifikasi yang dilakukan adalah penyederhanaan model dari empat tahap menjadi tiga tahap, yaitu: (1) Pendefinisian, (2) Perancangan, dan (3) Pengembangan. Data yang digunakan dalam penelitian ini meliputi proses pengembangan bahan ajar matematika berupa media pembelajaran berbasis macromedia flash. Untuk mengetahui apakah bahan ajar matematika berbasis macromedia valid, melalui pengukuran terhadap data kuantitatif berupa angket yang menggunakan skala likert. Teknik analisis data yang digunakan dalam penelitian ini adalah analisis deskriptif. Analisis data yang dilakukan adalah pada lembar validasi bahan ajar pada materi Perbandingan, skala, dan persen.

\section{HASIL PENELITIAN}

Bahan ajar yang telah dikembangkan adalah bahan ajar berbentuk media pembelajaran matematika untuk siswa SMK teknologi \& rekayasa pada materi operasi bilangan real. Bedasarkan keunggulan dari Macromedia Flash, bahan ajar yang dikembangkan untuk selanjutnya disebut sebagai media pembelajaran berbasis macromedia flash.

Tidak seperti media pembelajaran pada umumnya, media pembelajaran dalam bentuk CD pembelajaran matematika berbasis Macromedia Flash ini dirancang khusus untuk siswa SMK kelompok teknologi \& industri. Materi yang disampaikan lebih menekankan pada tujuan kontekstual \& aplikatif sesuai dengan tujuan pembelajaran matematika di SMK.

\section{Deskripsi Hasil Tahap Pendefinisian (define)}

Indentifikasi dilakukan terhadap bahan ajar matematika berbasis macromedia flash. Pada tahap ini, peneliti melakukan investigasi awal dan analisis kajian secara teoritis tentang (1) teori pengembangan, (4) teori macromedia flash, (5) matematika dalam penerapannya di bidang teknologi otomotif. Investigasi yang dilakukan peneliti melalui observasi, wawancara, dan mempelajari hasil-hasil penelitian sebelumnya.

\section{a. Analisis Ujung Depan}

Analisis ujung depan yang digunakan peneliti dalam memunculkan masalah sebagai dasar yang diperlukan untuk pengembangan bahan ajar diuraikan pada bagian pendahuluan, kemudian peneliti melakukan kajian teoritis mengenai matematika dalam penerapannya di bidang teknologi otomotif berkenaan dengan berlakunya Kurikulum. Kebutuhan siswa SMK khususnya kelompok Teknologi \& Industri, memunculkan ide-ide dalam mengembangkan bahan ajar yang sesuai dengan siswa. Analisis ini kemudian menjadi dasar bagi peneliti dalam mengembangkan bahan ajar berbasis macromedia flashuntuk materi perbandingan, skala, dan persen.

\section{b. Analisis Siswa}

Analisis ini dilakukan melalui kegiatanmengamati ciri dan kemampuan siswa secara individu dan kelompok. Siswa yang diamati adalah siswa yang kemudian dijadikan subjek penelitian yaitu siswa kelas $\mathrm{X}$ TMO 3. Hasil pengamatan peneliti, menunjukkan bahwa siswa cukup mampu berkooperatif dengan sesama temannya dan memiliki kesamaan karena hamper seluruh siswa adalah laki-laki. Hasil wawancara dengan wali kelasnya, menunjukkan bahwa siswa kelas X TMO 3 tergolong siswa yang dapat dikategorikan normal dalam rentang usia 18 - 21 tahun dan dengan latar belakang keluarga yang hampir sama.

\section{c. Analisis Materi}

Analisis materi bertujuan untuk mengidentifikasi bagian-bagian utama yang akan diajarkan dan disusun secara sistematis. Analisis ini yang menjadi dasar dalam penyusunan tujuan pembelajaran. Analisis topik/materi yang dilakukan peneliti pada materi operasi bilangan real khususnya pada topikperbandingan, skala dan persen.

\section{d. Analisis Tugas}

Hasil analisis tugas materi Operasi Bilangan Real untuk SMK Teknologi \& Rekayasa adalah memahami konsep Operasi Bilangan Riil serta penerapannya dalam 
pemecahan masalah. Oleh karenanya, kemampuan keterampilan pemecahan masalah dalam kehidupan sehari-hari melalui proses aplikasi matematika dalam kehidupan sehari-hari menjadi sebuah tolak ukur keberhasilan pembelajaran matematika materi Operasi Bilangan Real di SMK Teknologi dan Rekayasa.

\section{e. Spesifikasi Tujuan Pembelajaran}

Sesuai dengan analisis tugas yang telah dilakukan, spesifikasi tujuan yang merupakan indikator pencapaian proses belajar adalah kemampuan siswa dalam menyelesaikan masalah program keahlian yang berkaitan dengan Operasi Bilangan Real.

\section{Deskripsi Hasil Tahap Perancangan (design)}

Perancangan prototipe bahan ajar matematika berbasis macromedai flashmateri Operasi Bilangan Real kelas X SMK Teknologi dan Rekayasa dimulai setelah peneliti menetapkan tujuan pembelajaran. Pada tahap ini telah dihasilkan prototipe (Draft 1) bahan ajar matematika berbasis macromedia flash.

\section{Deskripsi Hasil Pengembangan Bahan Ajar (develope)}

Bahan ajar yang telah dikembangkan adalah bahan ajar matematika untuk SMK Teknologi \& Industri berbasis Macromedia Flash untuk Materi Operasi Bilangan Real pada Pokok Bahasan Perbandingan, Skala, dan Persen. Bahan ajar dalam bentuk CD Pembelajaran, yang memuat 30 frame.

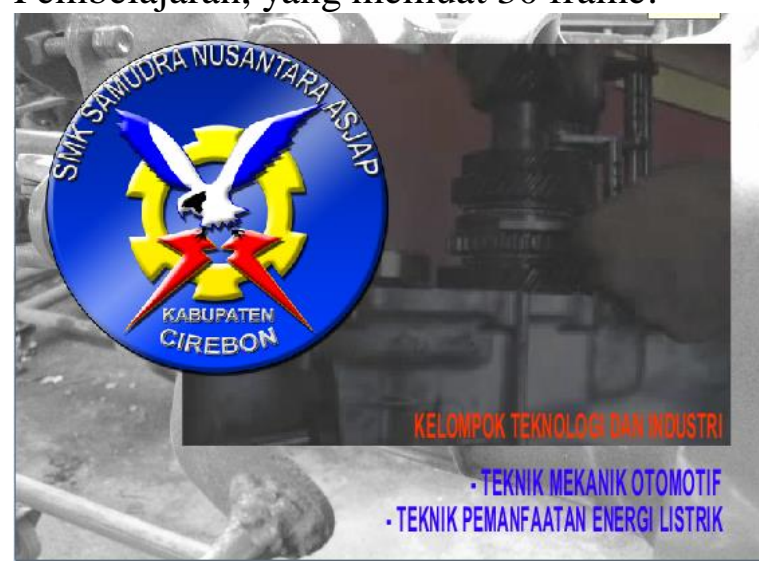

Gambar 1. Frame Tampilan Pembuka

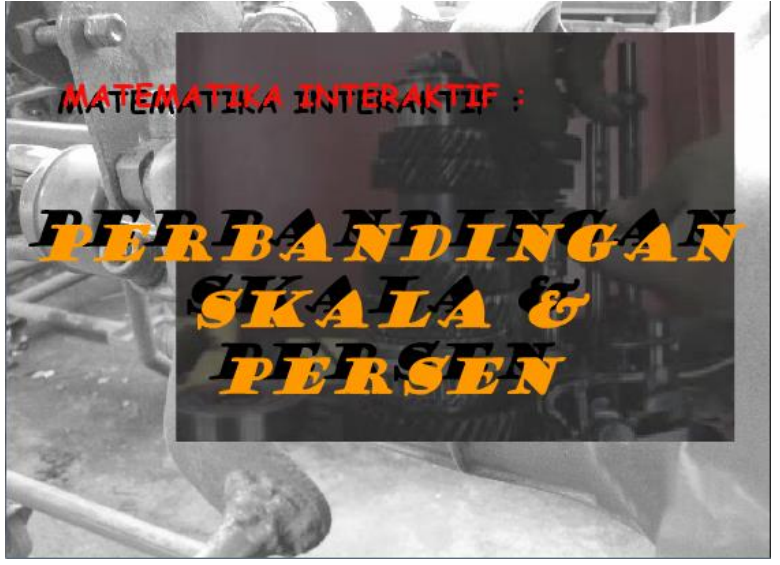

Gambar 2 Frame Judul

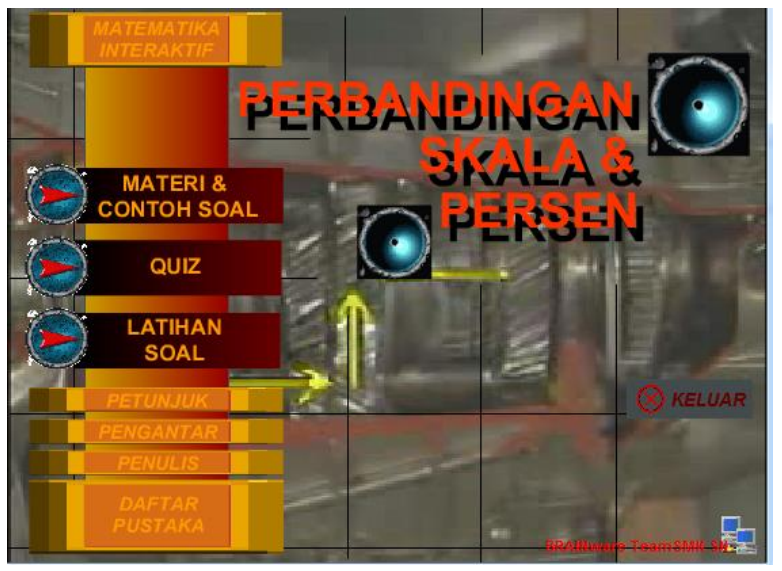

Gambar 3 Frame Tampilan Menu Utama

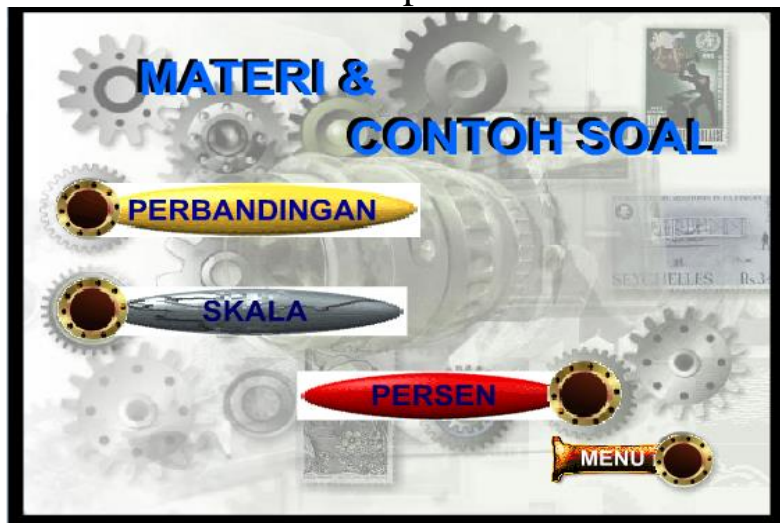

Gambar 4 Frame Tampilan Materi \& Contoh Soal

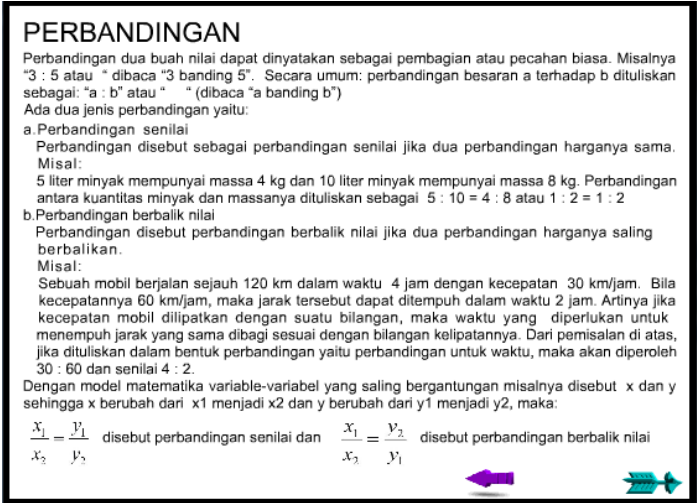

Gambar 5. Frame Materi Perbandingan 


\section{SKALA}

Skala ialah bentuk perbandingan senilai ukuran suatu besaran nyata. Simbol untuk menyatakan skala a cal

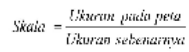

Penulisan skala untuk besaran atau satuan yang tidak sejenis, dituliskan dengan satuan-satuannya Misalnya $1 \mathrm{~cm}$ paniang ukuran menyatakan gaya $200 \mathrm{~N}$, dituliskan sebagai $1 \mathrm{~cm}: 200 \mathrm{~N}$

Contoh 1

Jarak 2 kota pada peta $7,5 \mathrm{~cm}$. Jika skala peta $1: 150.000$, berapakah jarak sesungguhnya?

$$
\begin{aligned}
\text { Jarak sesungguhnya } & =7,5 \times 150.000 \\
& =1.125 .000 \mathrm{~cm} \\
& =11,25 \mathrm{~km}
\end{aligned}
$$

Contoh 2
Sebuah ulir sepanjang $35 \mathrm{~cm}$ akan digambar dengan menggunakan skala $1: 10$. Berapakah panjang ulir pada gambar?

Pembahasan :

$$
\begin{aligned}
\text { Ukuran Peta } & =\text { skala } \mathrm{x} \text { ukuran sebenarnya } \\
& =\frac{1}{10} \times 35 \\
& =3,5 \mathrm{~cm}
\end{aligned}
$$

Gambar 6 Frame Materi \& Contoh Soal Skala

\section{PERSEN}

Suatu pecahan dapat dituliskan dalam 3 cara:

A.Pecahan biasa, misal : $\frac{3}{10}$

B.Desimal

Desimal menggunakan nilai tempat, $\frac{1}{10}, \frac{1}{110}$, dan seterusnya

Misal: $\frac{75}{100}=0,75$ Angka 7 nilainya 7 persepuluh, angka 5 nilainya 5 perseratus

Cersen adalah bentuk lain dari pecahan yang penyebutnya seratus. Symbol yang digunakan untuk menyatakan persen adalah *\%"

nya Untuk mengubah bentuk persen manjadi pecahan, dilakukan dengan jalan membagi persen tersebut dengan $100 \%$. Misalnya:
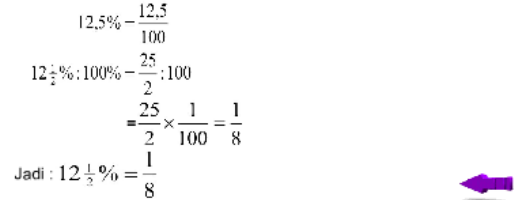

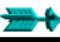

Gambar 7 Frame Materi Persen

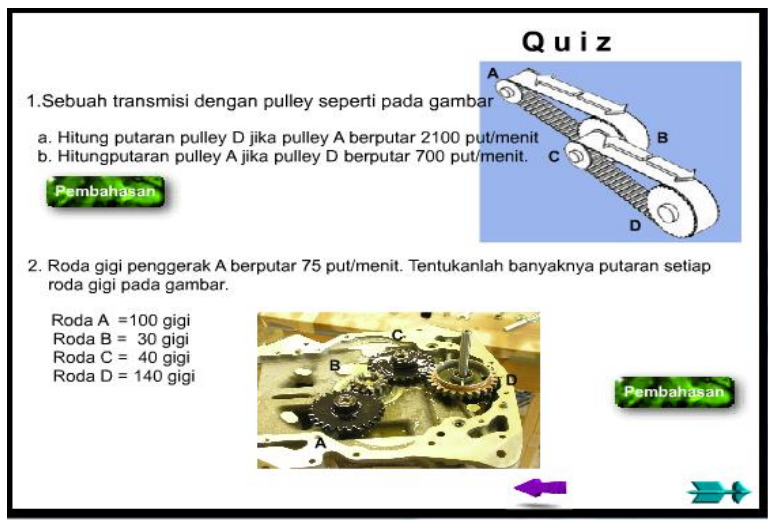

Gambar 8 Frame Quiz

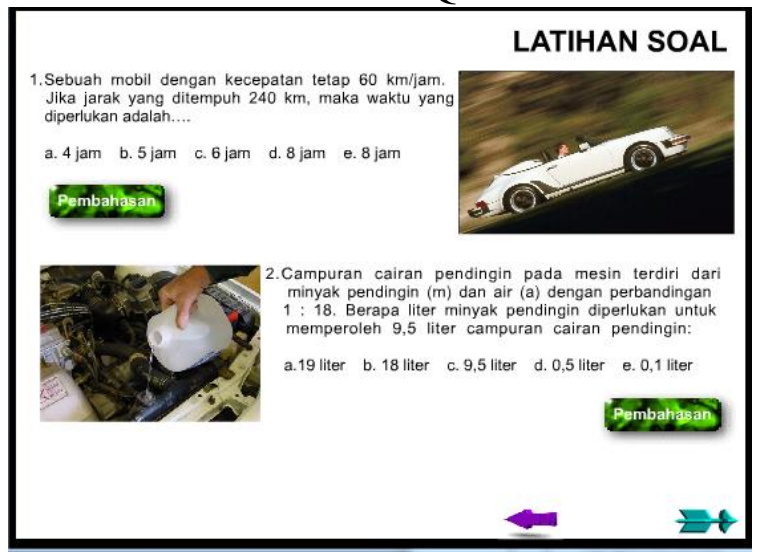

Gambar 9 Frame Tampilan Latihan Soal

\section{PETUNJUK}

Program tutorial matematika berbasis komputer ini merupakan perangkat pembelajaran dengan dengan menggunakan media komputer minimal Pentium $11-450 \mathrm{MHz}$ dengan
RAM $64 \mathrm{Mb}$. Program tutoriat ini terdiri atas beberapa menu yaitu:

1.Petunjuk $\rightarrow$ Berisi informasi penggunaan software.
2.Pengantar $\longrightarrow$ Berisi hat yang melandasi pembuatan MATEMATIKA INTERAKTIF 3.Materi \& $\rightarrow \begin{aligned} & \text { dengan pokok bahasan Perbandingan, Skala, dan Persen. } \\ & \text { Berisi materi disertai dengan contoh soal berikut pembahasannya. }\end{aligned}$

4. Quiz $\rightarrow$ Berisi latihan yang diselesaikan pada saat KBM

4. Quiz $\rightarrow$ B $\rightarrow$ Bathat

6.Daftar Pustaka $\rightarrow$ Berisi daftar pustaka yang digunakan sebagai bahan untuk

pembuatan MATEMATIKA INTERAKTIF ini.

7.Penulis $\rightarrow$ Berish, balaman untuk mengetahui informasi tentang penulis

8.Keluar $\ldots .>$ Berisi perintah untuk mengakhiri penggunaan MATEMATIKA INTERAKTIF ini. (Klik "Ya" bila yakin akan ka
bila ingin membatalkan keluar dari program). bila ingin membatalka

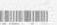

Gambar 10 Frame Tampilan Petunjuk

\section{PENGANTAR}

Matematika merupakan suatu alat untuk berkomunikasi di bidang ilmu pengetahuan dan den teknik. Kita sering melikat kita dapat mengungkapkan gejala-gejala alam, sosial peta kecil dalam selembar kertas. Pad belajar begaimana aplikasi perbandingan, menghitung skala dan persen pada hehidupan seharitar tormasukjuga dalam dunia teknik.

STANDAR KOMPETENSI: OPERASI BILANGAN REAL

KOMPETENSI DASAR : PERBANDINGAN, SKALA DAN PERSEN

INDIKATOR
Setelah mempelajari materi pada kompetensi dasar ini, siswa diharapkan dapat:

1.Menyelesaikan persoalan yang mengandung perbandingan senilai.

3.Menyatakan ukuran sebenaroya jika ukuran pada gambar dan skalanya diketahui.

4.Mengubah pecahan biasa menjadi bentuk desimal.
5.Menghitung presentasi suatu bilangan terhadap bilangan lain.

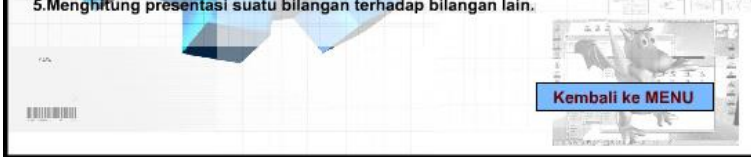

Gambar 11 Frame Tampilan Pengantar

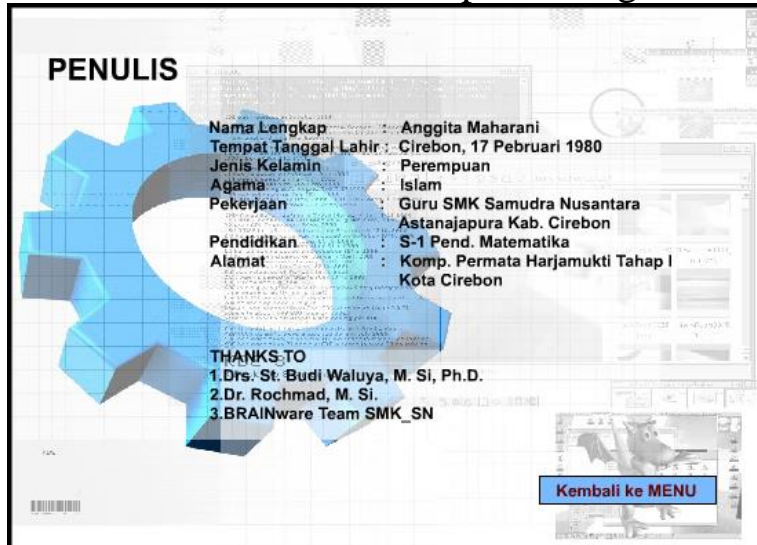

Gambar 12 Frame Tampilan Penulis

\section{DAFTAR PUSTAKA}

Arry, S. Bandung Dkk, (2008). Matematika SMK Bisnis dan Manajemen. Jakart Depdiknas.

Maharani, A. (2009). Modüi Materi dan Latihan Ujian Nasional Matematika SMK Kelompok Teknologi \& Industri. Cirebon: SMK SN.

Sariadi, Fadilah K, Adi R. (2002), Instalasi Listrik Industri. Bandung: Angkasa

Wiyoto \& Wagirin. (2002). Matematika Sekolah. Menengah Kejuruan Bidang Keahlian Teknologi dan Industri. Bandung: Angkasa.

Wiyoto.(1996). Matematika Teknjk Julid I. Bandung: Angkasa.

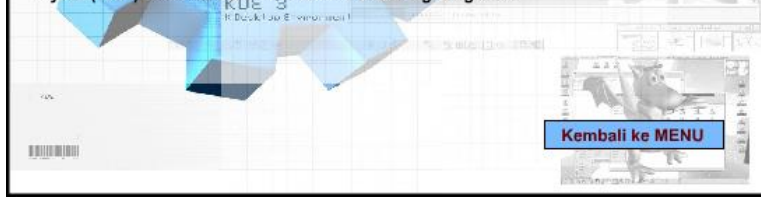

Gambar 13 Frame Tampilan Daftar Pustaka 


\section{DeskripsiHasilValidasi pada Tahap Pengembangan}

Kegiatan yang dilakukan tahap ini adalah analisisprosespengembangandari draft awal menjadi prototipe 1 bahan ajar matematika berbasis macromedia flash. Pada tahap ini diselidiki validitas draft awal bahan ajar yang kemudian menjadi prototipe 1 . Kemudian dilanjutkan dengan implementasi prototipe 1 bahan ajar, yang berkenaan dengan tes empirik dan evaluasi.

Deskripsi hasil validasi ahli media

Berdasarkan data kuantitatif dari hasil validasi, dapat dihitung prosentase pencapaian kevalidan bahan ajar matematika berbasis macromedia flash ini sebagai berikut:

$$
\begin{gathered}
P=\frac{\sum X}{\sum X_{1}} \times 100 \% \\
P=\frac{61}{65} \times 100 \%=94 \%
\end{gathered}
$$

Berdasarkan hasil perhitungan, maka dapat dikatakan bahwa bahan ajar yang telah dikembangkan termasuk ke dalam kategori valid.

\section{Deskripsi hasil validasi Ahli Isi/Materi}

Berdasarkan data kuantitatif dari hasil validasi, dapat dihitung prosentase pencapaian kevalidan bahan ajar matematika berbasis macromedia flash ini sebagai berikut:

$$
\begin{gathered}
P=\frac{\sum X}{\sum X_{1}} \times 100 \% \\
P=\frac{69}{75} \times 100 \%=92 \%
\end{gathered}
$$

Berdasarkan hasil perhitungan, maka dapat dikatakan bahwa bahan ajar yang telah dikembangkan termasuk ke dalam kategori sangat valid.

\section{Deskripsi hasil validasi Ahli Pembelajaran}

Berdasarkan data kuantitatif dari hasil validasi, dapat dihitung prosentase pencapaian kevalidan bahan ajar matematika berbasis macromedia flash ini sebagai berikut:

$$
P=\frac{\sum X}{\sum X_{1}} \times 100 \%
$$

$$
P=\frac{106}{115} \times 100 \%=92 \%
$$

Berdasarkan hasil perhitungan, maka dapat dikatakan bahwa bahan ajar yang telah dikembangkan termasuk ke dalam kategori sangat valid.

\section{Simpulan}

Berdasarkan proses dan hasil penelitian pengembangan diperoleh kesimpulan sebagai berikut:

1. Proses produksi dalam rangka mengambangkan bahan ajar matematika untuk SMK materi Operasi Bilangan Real pokok bahasan Perbandingan, Skala dan Persen menggunakan software macromedia flash. Bahan ajar yang sudah dalam bentuk CD Pembelajaran divalidasi oleh beberapa ahli diantaranya ahli media dan ahli materi untuk mengetahui sekaligus menguji kelayakannya. Validator diberi beberapa pertanyaan dalam bentuk angket.

2. Melalui proses penelitian pengembangan bahan ajar dengan memodifikasi modelFour-D yang meliputi tahap pendefinisian dan perancangan, telah dihasilkan protitipe bahan ajar matematika berbasis macromedia flash untuk materi Operasi Bilangan Real Kelas X SMK Teknologi dan Rekayasa. Bahan ajar yang dikembangkan merupakan bahan ajar matematika berbasis macromedia flash yang desainnya memuat permasalahan dalam kehidupan sehari-hari khususnya dalam aplikasi Operasi Bilangan Real terhadap perhitungan teknik otomotif sebagai starter point dalam belajar. Melalui proses pertimbangan dan penilaian ahli dan teman sejawat, diperoleh bahan ajar berbasis macromedia flash materi Operasi Bilangan Real Kelas X SMK Teknologi dan Rekaya sayang valid.

\section{Saran}

Beberapa saran yang dapat diungkapkan bagi pengguna serta calon peneliti pengembangan lebih lanjut adalah. 
1. Bahan ajar matematika berbasis macromedia flash ini dapat digunakan sebagai alternatif dalam penyampaian materi bagi siswa SMK Khususnya Kelompok Teknologi \& Rekayasa.

2. Bahan ajar berbasis macromedia flash ini selanjutnya dapat dikembangkan sesuai dengan kebutuhan siswa.

3. Penelitian ini masih dapat dilanjutkan dengan melakukan uji coba, mengingat keterbatasan waktu sehingga penelitian ini belum sempat diuji cobakan bsecara terbatas maupun secara luas.

4. Hasil penelitian ini juga masih dapat dilanjutkan dengan menganalisis secara kualitatif hasil validasi serta menguji keefektifannya, mengingat penelitian ini baru sampai tahap pengembangan.

\section{DAFTAR RUJUKAN}

Chang, K.-E., Sung, Y.-T., \& Hou, H.-T. (2006). Web-based Tools for Designing and Developing Teaching Materials for Integration of Information Technology into Instruction. Educational Technology \& Society, 9 (4), 139-149.

Direktorat Pembinaan SMA. (2010). Juknis Pengembangan Bahan Ajar SMA. Jakarta: Dikmen.

Halidi, dkk. (2015). Pengaruh Media Pembelajaran Berbasis TIK Terhadap Motivasi dan Hasil Belajar IPA Siswa Kelas V SDN Model Terpadu Madani Palu. e-Jurnal Mitra Sains, Volume 3 Nomor 1, Januari 2015 hlm 53-60.

Kementrian Komunikasi dan Informasi Republik Indonesia. (2015). Hasil Survey Indikator TIK 2015. Komfindo: Tim Indikator TIK Puslitbang PPI.

Permendikbud. (2014). Peraturan Menteri Pendidikan dan Kebudayaan Republik Indonesia Nomor 60 Tahun 2014 Tentang Kurikulum 2013 Sekolah
Menengah Kejuruan/Madrasah Aliyah Kejuruan. Jakarta: Depdikbud.

Rahman dkk. (2008). Optimalisasi Macromedia Flash Untuk Mendukung Pembelajaran Berbasis Komputer Pada Program Studi Ilmu Komputer FPMIPA UPI. Jurnal Pendidikan Teknologi Informasi dan Komunikasi, ISSN:1979-9264 Volume 1, Nomor 2, Desember 2008.

Trianto. 2007. Model Pembelajaran Terpadu dalam Teori dan Praktek. Surabaya: Prestasi Pustaka Publisher 
(XIC(.)llid Jurnal Teori dan Riset Matematika (TEOREMA) Vol. 2 No. 1, Hal, 10-10, September 2017 p-ISSN 2541-0660, e-ISSN 2597-7237 @ 2017 